Discussion Paper No. 06-064

\title{
Basic Income Reform in Germany: Better Gradualism than Cold Turkey
}

Alexander Spermann

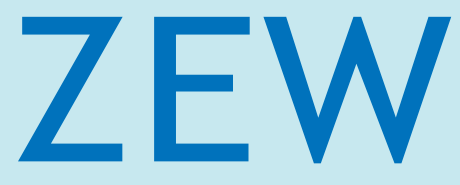

Zentrum für Europäische Wirtschaftsforschung $\mathrm{GmbH}$

Centre for European

Economic Research 
Discussion Paper No. 06-064

\title{
Basic Income Reform in Germany: Better Gradualism than Cold Turkey
}

\author{
Alexander Spermann
}

Download this ZEW Discussion Paper from our ftp server:

ftp://ftp.zew.de/pub/zew-docs/dp/dp06064.pdf

Die Discussion Papers dienen einer möglichst schnellen Verbreitung von neueren Forschungsarbeiten des ZEW. Die Beiträge liegen in alleiniger Verantwortung der Autoren und stellen nicht notwendigerweise die Meinung des ZEW dar.

Discussion Papers are intended to make results of ZEW research promptly available to other economists in order to encourage discussion and suggestions for revisions. The authors are solely responsible for the contents which do not necessarily represent the opinion of the ZEW. 


\section{Non-technical summary}

The main problems on the German labor market are long-term unemployment and joblessness among the low skilled, although both problems do of course overlap. Despite the Hartz reforms, the long-term unemployment rate has leapt up in recent years and - as defined by the OECD - reached $51.8 \%$ in 2004 . According to figures published by the Federal Labor Institute, there has been a continuous increase in the number of long-term unemployed since 2001 . The unprecedentedly high figures for 2005 were over 1.8 million long-term jobless. The trend among the low skilled without professional qualifications in Germany has been one of consistently rising unemployment since the 1970s; in western Germany in 2004 over $20 \%$ of this group was unemployed, in eastern Germany over $50 \%$. The situation is truly dramatic. Reform is more urgently required than ever.

This paper advocates the cautious and constitutional evolution of existing unemployment benefit instruments (Arbeitslosengeld II = ALG II) and Targeted Negative Income Tax (TNIT = "Einstiegsgeld") under Paragraph 29 of the German Social Code (SGB II) into a means-tested combi-wage model for the future long-term unemployed (gradualism strategy). The proposed four component model is a combi-wage model within the existing basic income support system. The four component model consists of 1 . degressive unemployment benefit (Arbeitslosengeld I) reduced stepwise over 12 months (insurance component), 2. a time-restricted income supplement up to the poverty line (TNIT component), 3. an indefinite entitlement to ALG II equivalent to a subsistence minimum (poverty gap concept component), and 4 . an absorbing community or voluntary work element (workfare components). 
As far as the three million existing unemployed ALG II claimants are concerned, this paper only argues for an additional, time-restricted income supplement (TNIT) up to the poverty line for each household type coupled with a stringently enforced duty to seek and accept work - with the aim of providing current unemployment II claimants with a powerful incentive to work at least 15 hours a week and thus to relinquish their unemployed status.

Bearing in mind the uncertain employment impact and the related fiscal risks, the paper advises against additional financial incentives by reducing support levels from one day to the next (cold turkey strategy). In other words, the model represents a gradualist carrot-and-stick strategy intended to make low-paid jobs more attractive to the long-term unemployed. 


\title{
Basic Income Reform in Germany: Better Gradualism than Cold Turkey
}

\author{
Alexander Spermann ${ }^{*}$
}

Abstract

This paper advocates the cautious and constitutional evolution of existing basic income schemes ("unemployment benefit II") and Targeted Negative Income Tax (TNIT = "Einstiegsgeld") into a means-tested combi-wage model for the future long-term unemployed (gradualism strategy). The paper argues that, with regard to existing unemployment benefit II claimants, stronger financial incentives should be offered on a time restricted basis by largely disregarding (up to the relative poverty line) earnings from "mini", "midi" and part-time jobs - with the aim of providing current unemployment II claimants with a powerful incentive to work at least 15 hours a week and thus to relinquish their unemployed status. Bearing in mind the uncertain employment impact and the related fiscal risks, the paper advises against additional financial incentives by reducing support levels from one day to the next (cold turkey strategy).

Keywords: Labor Market Reform, Employee Subsidy, Workfare, longterm unemployment

J EL classifications: I 38, J 22

\footnotetext{
* Alexander Spermann, Centre for European Economic Research (ZEW), PO Box 103443, D-68034 Mannheim, spermann@zew.de
} 


\section{I ntroduction}

After more than ten years of debate on wage subsidies (combi-wage) the year 2006 may finally bring the breakthrough: The 'grand coalition' is planning a legislative initiative on the combi-wage for the autumn of 2006. The government will be able to draw on the lessons learned from a large number of pilot schemes which have been run in recent years in Germany (cf. Kaltenborn 2001, 2005 and Dietz et al. 2005). The relevant debate has taken on board numerous proposals originating from the academic world, business and industry associations and the political parties - the FDP's suggestion of a citizen's wage, the ifo Institute's Combi-Wage Model (cf. Sinn et al. 2002, 2006) and the Magdeburger Alternative (cf. Schöb/Weimann 2005) are the concepts on which most debate has focused, although the respective pros and cons of each are not examined in this paper (cf. Spermann 2006 for a more detailed discussion). Instead, this paper presents a reform proposal which is based on practical experience with Targeted Negative Income Tax (TNIT) in Germany. Initially, however, the paper discusses the key problems on the labor market and the dynamic relationship between the duty to work and the financial incentives built into the design of a basic income support system (Chapter 2). Chapter 3 presents a simplified diagram, supported by recent basic income statistics, of the distorting incentive effects associated with the unemployment trap which contribute to prolonging periods of joblessness. The four-component model of fair basic income support based on insurance, TNIT, poverty gap concept, and workfare components, is presented in Chapter 4. Chapter 5 discusses the potential employment and fiscal effects while Chapter 6 elaborates the advantages of a gradualist compared with a cold turkey strategy. Chapter 7 provides a brief conclusion. 


\section{Key Problems on the Labor Market and the Design of Basic Income Support}

Dramatic Increase in Numbers of Long-Term and Low-Skilled Unemployed

The main problems on the German labor market are long-term unemployment and joblessness among the low skilled, although both problems do of course overlap (cf. Sachverständigenrat - the German Council of Economic Experts - 2005). Despite the Hartz reforms, the longterm unemployment rate has leapt up in recent years and - as defined by the OECD - reached $51.8 \%$ in 2004 (cf. OECD 2005). According to figures published by the Federal Labor Institute (Bundesagentur für Arbeit), there has been a continuous increase in the number of long-term unemployed since 2001. The unprecedentedly high figures for 2005 were over 1.8 million long-term jobless (cf. Federal Labor Institute 2005). The trend among the low skilled with without professional qualifications in Germany has been one of consistently rising unemployment since the 1970s; in western Germany in 2004 over 20\% of this group was unemployed, in eastern Germany over 50\% (cf. Reinberg/Hummel 2005). The situation is truly dramatic. Reform is more urgently required than ever.

Dramatic Surge in the Number of People Receiving Basic Income Support

The "basic jobseeker's allowance" (so-called unemployment benefit II = Arbeitslosengeld II = ALG II) was introduced throughout Germany under the German Social Code SGB II at the beginning of 2005. This entailed the merging of social assistance (Sozialhilfe) for claimants who are fit to work with unemployment assistance (Arbeitslosenhilfe) into a single new means-tested and tax-financed transfer system. In March 2004, the official administrative bodies anticipated that the new basic allowance 
would be paid to around 3 million claimants. However, in March 2006 the actual figures for claimants of the basic allowance under SGB II is over 7 million - more than twice as many as originally expected.

The explanation for this development basically lies in two politically determined definitions which were not current in quite the same form prior to the reform. On the one hand, 'capacity to work' was defined in such broad terms that even drug addicts who were very unlikely to find a job were, for example, defined as available for work. On the other, the term low income household (Bedarfsgemeinschaft or a household entitled to receive benefits) was also defined in a way which created incentives for young adults to move out of their parental homes to form new low income households - with the result that in the space of a very short time the number of low income households rose to almost four million. In March 2006, 5.2 million people were on ALG II and 1.85 million people - mainly children - were on social allowances (Sozialgeld) so that, in total, over 7 million people were in receipt of basic income support under SGB II (cf. Federal Labor Institute 2006 a,b).

Unemployed Claimants of Basic Income Support and of Combi-Wages

From a labor market policy perspective, two subgroups of ALG II claimants are of particular significance. The almost three million registered unemployed ALG II claimants must be considered separately. A person is defined as unemployed if he or she works fewer than 15 hours a week. On the other hand, there are also over 900,000 people in work who also receive basic income support (cf. Federal Labor Institute 2006c). Unfortunately these subgroups overlap as the available statistics do not specify how many working claimants of ALG II are no longer registered unemployed because they are working over the threshold value of 15 hours/week. A more detailed statistical breakdown is required to distinguish these two subgroups. 
Failure to Enforce the Duty to Seek and Accept Work

In Germany claimants of ALG II are subject to a duty to seek and accept work. With the introduction of the Job Center and the tightening up of suitability criteria requiring claimants to accept work under the Hartz laws, the duty to accept suitable jobs is much tougher than in the past, even if considerable regional differences persist. Even though the basic jobseeker's allowance has now been in force for over a year, Job Centers are still in the process of being set up. Case management in the working parties comprising the Federal Labor Institute and local authorities (ARGEn) is - apart from one or two exceptions - nothing like as intensive as that undertaken by the local labor offices themselves. A popular lament at the time this paper was written is that "in den ARGen noch viel im Argen liegt" (or "it's no party in the working parties"), particularly because the envisaged ratio of case managers to unemployed claimants has not yet been achieved. The situation is exacerbated by IT problems which eat up case manager's scare client contact time owing to the sheer volume of data which needs to be entered and corrected manually. However, in reality the duty to seek and accept work cannot be enforced if intensive case management is not available.

But even if these transitional difficulties were to be solved in the near future, the absence of an automatic mechanism for reducing benefits and regular involvement of officially appointed doctors means that imposing benefit sanctions for those refusing a job is likely to remain an enduring problem. Although case managers are able to resort to "one-euro jobs" (in effect additional jobs) as a means of verifying a claimant's willingness to accept work, claimants are always entitled to lodge objections to, or bring an action against, any benefit reductions whilst claiming legal aid to cover all their court costs. As a result, case managers are currently having to 
bear a huge increase in administrative work and consequently have less time available to support other clients.

Is it Enough to Impose Compulsory Activation Requirements on Claimants Without Providing Financial Incentives?

At first glance a consistently enforced duty on claimants receiving jobseeker's allowance to seek and accept work might appear to make additional financial incentives in the form of improved additional earnings options superfluous. However, compulsory activation is seriously hampered by the near impossibility of precisely assessing capacity to work in hourly categories (e.g. 5, 10, 15, 20 etc. hours). If we assume that officially appointed doctors are able to dictate a minimum hour working load (e.g. three hours a day) at reasonable costs, the more stringent the state is in urging compliance with compulsory activation policies, the more likely it is that people will accept work (participation decision). However and this is the decisive argument in favor of additional financial incentives - the amount of time which individuals choose to spend beyond this administered threshold depends critically on the disregard rules in the transfer system (working hours decision). What is more, in a system in which work obligations are perfectly enforced and consistent benefit sanctions are imposed on those refusing to accept a job, there is a very strong incentive to acquire incapacity to work status in order to continue receiving benefits. The lessons learned by military draft boards have amply demonstrated how imaginative people can be in this respect. Nonetheless, it is still worthwhile thinking about the existing financial incentives for claimants receiving jobseeker's allowance and the way they respond to these rules, as well as about alternative arrangements. Enforcing the duty to work is a necessary but not a sufficient condition for tackling key labor market problems. 


\section{Distorting I ncentives Effects and the Unemployment Trap in 2006}

The status quo of ALG II claimants in the year 2006 is illustrated more clearly by considering a simplified gross / net earnings diagram (Figure 1) drawing on the disregard rules which have been in force since October 1 , 2005.

The average basic income support for a single person in western Germany is assumed to be $€ 575$. This amount is composed of a basic allowance of $€ 345$ and an amount to cover the combined costs of housing and heating of $€ 230$. Income earned by claimants is subject to a disregard of $€ 100$. The benefit reduction rate on earnings between $€ 100$ and $€ 800$ is $80 \%$ ( $t=0.8$ ), while claimants earning between $€ 800$ and $€ 1200$ have $90 \%$ of their additional earnings deducted from their benefit entitlement $(t=0.9)$. The figures in this simplified example, which takes account of social security contributions and income tax, demonstrate that supplementary ALG II is paid to single people with gross earnings of up to $€ 1,100$. The case in which own earnings are (almost) entirely swallowed up by a reduction in benefit is referred to as the unemployment trap. Given the way the benefit withdrawal tables for single households work, it would hardly be worthwhile for a claimant on jobseeker's allowance to accept a mini job (€400) from which the claimant would only take home an extra $€ 160$. 


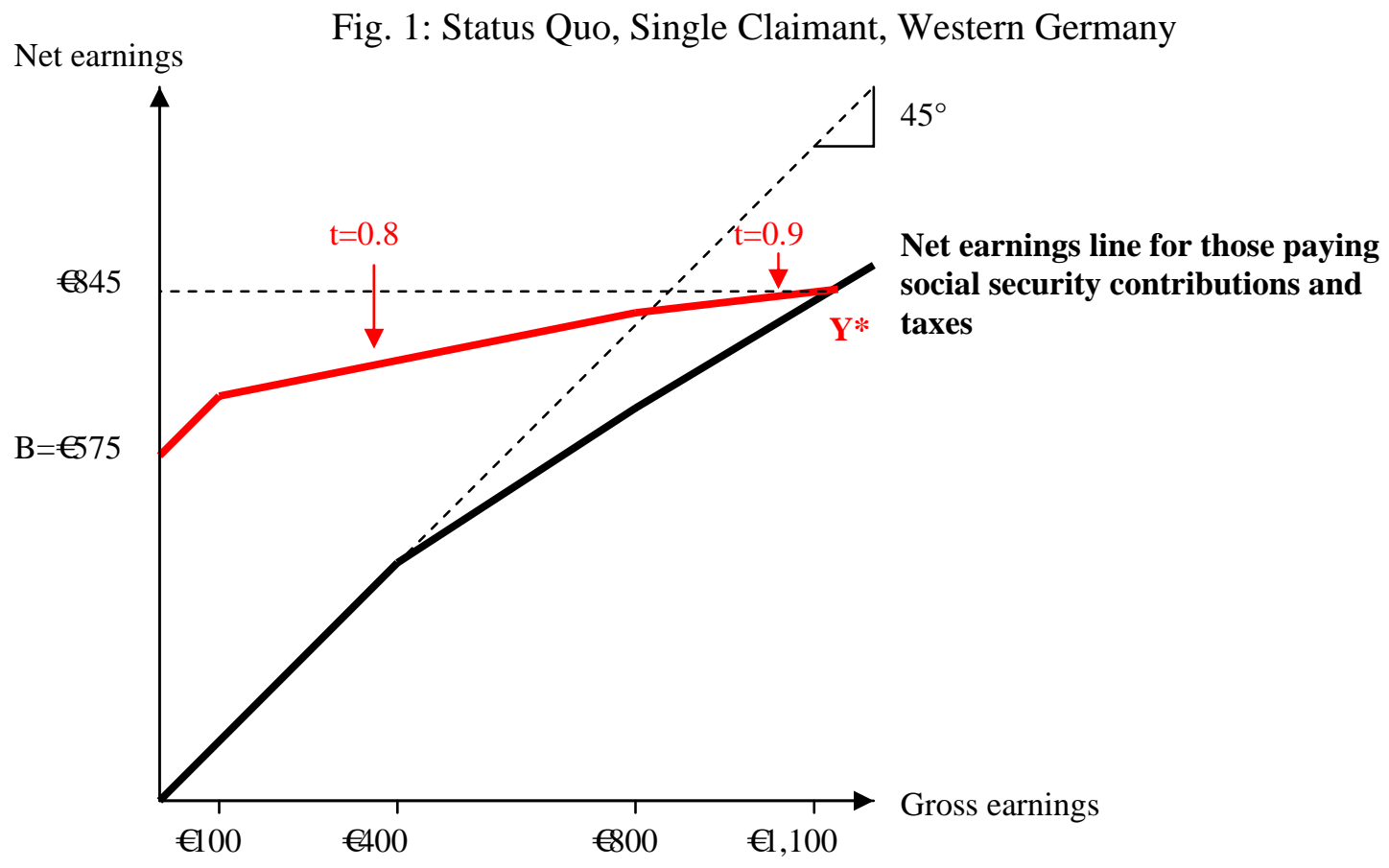

The unemployment trap is even more egregious for a family with two children (western Germany). The basic income support is significantly higher at $€ 1,471$ and is comprised of the basic allowance for two adults ( $€ 311$ each), for two children under 14 ( $€ 207$ for each child) and the costs of housing and heating amounting, in average, to €435. The additional earnings options are calculated as above, although the $90 \%$ withdrawal rule applies on earnings up to $€ 1,500$ for low income household with children. Over and above this gross earnings level, additional income is withdrawn in full $(t=1)$. Claimants are entitled to supplementary ALG II if their gross earnings are below around $€ 2,400\left(Y^{*}\right)$. 
Fig. 2: Status Quo, Family (2 Children), Western Germany

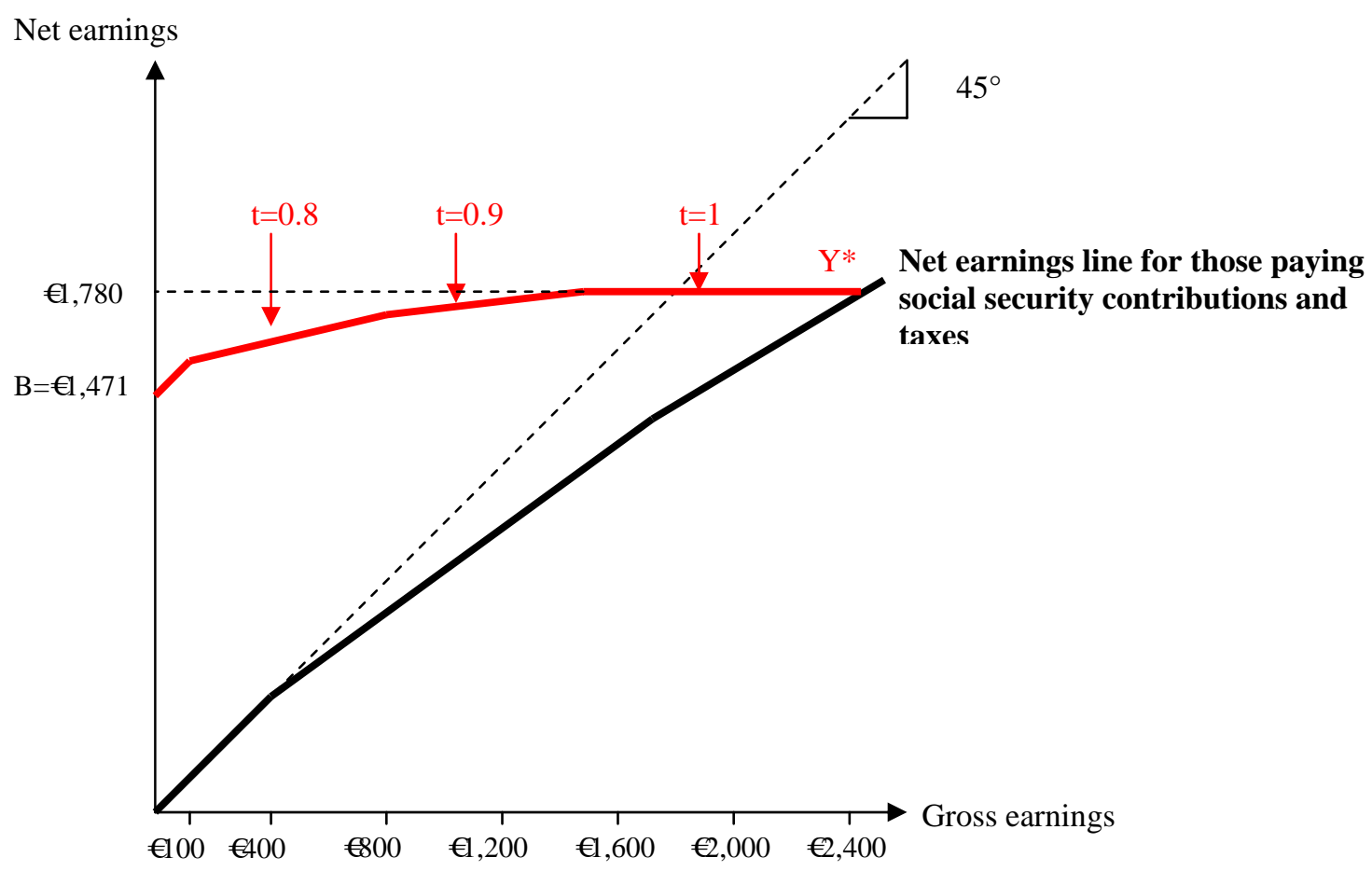

This clearly demonstrates how difficult it is for families in particular to escape from the transfer system, even those that make very great efforts to do so. If both partners were to accept full-time jobs on a wage of $€ 5$ an hour their joint earnings for working two 40-hour weeks would be around $€ 1,600$, which means that even in this case of full-time employment there would still be no alternative but to continue paying the family supplementary ALG II unless the hourly wage were to rise significantly.

Empirical Relevance of the Unemployment Trap

Differentiated empirical evaluations of the gainful employment of ALG II claimants are now available for September 2005 - a period in which disregard rules which were considerably more restrictive than those considered above were in force. The available figures show that around $20 \%$ of ALG II claimants - 906,000 people in 844,000 low income 
households - were in gainful employment (cf. Federal Labor Institute 2006c). Two phenomenon or behavioral responses are apparent:

(a) "Stealth" employment

Directors of security departments and job centers have provided anecdotal evidence of "stealth" employment when the pressure on people to accept work increases. Marginal employment is accepted, for example, in order to meet the legal requirement to seek and accept work and to avoid a reduction in benefit entitlement. This phenomenon is also substantiated by the latest evaluations performed by the Federal Labor Institute: more than half of all claimants work below the marginal earnings threshold of $€ 400$ Euro - with a remarkably high frequency of jobs paying between $€ 100$ and $€ 200$ (gross earnings).

(b) The working and the hidden poor

Low skilled people, who are not only in marginal employment, but whose net earnings only just cover their basic needs, are often referred to as the working poor. The hidden poor are those do not claim their full entitlement to state transfer payments because of perceived stigma or because they are inadequately informed.

Prior to the introduction of ALG II, several hundred thousand people were estimated to be living in hidden poverty because they failed to submit claims to the social security offices. Job centers appear to be less stigmatized than social security offices. One indication of this is the increase in the number of people entitled to submit supplementary claims. The number of claimants in gainful employment doubled, for example, from almost 470,000 previous social and unemployment assistance claimants to 906,000 ALG II recipients. However, this must be qualified by noting that no information was available about the number of hours worked or the distribution of gross earnings among people previously receiving social and unemployment assistance. 
Basic income reform must therefore take account of the fact that claimants in "stealth" employment are able to settle down permanently in the transfer system without having to fear having their benefits cut - and that they need to be enticed away from the transfer system with incentives. The number of claimants may also rise dramatically if claims are made for people in densely populated gross earnings categories. Accordingly, a reform of this nature would have to be implemented with great caution - not least because of the lack of comprehensive empirical knowledge and the imponderables concerning the response of those affected.

\section{Proposed Solution: The Four-Component Model of Fair Basic Income Support: a Means-Tested Combi-Wage Model for the Long- Term Unemployed}

This paper advocates the cautious and constitutional evolution of existing unemployment benefit instruments (ALG II) and Targeted Negative Income Tax ("Einstiegsgeld") under Paragraph 29 of the German Social Code (SGB II) into a means-tested combi-wage model for the future longterm unemployed (gradualism strategy). The four component model is a combi-wage model within the existing basic income support system. ALG II is the equivalent of an indefinite entitlement to income supplement; Targeted Negative Income Tax (TNIT or "Einstiegsgeld") on the other hand is time-restricted income supplement. As far as the three million existing unemployed ALG II claimants are concerned, this paper only argues for an additional, time-restricted income supplement (TNIT) up to the poverty line for each household type coupled with a stringently enforced duty to seek and accept work. In other words, the model represents a gradualist carrot-and-stick strategy intended to make lowpaid jobs more attractive to the long-term unemployed. 
The four component model consists of 1 . degressive unemployment benefit (ALG I) reduced stepwise over 12 months (insurance component), 2. a time-restricted income supplement up to the poverty line (TNIT component), 3. an indefinite entitlement to ALG II equivalent to a subsistence minimum (poverty gap concept component), and 4 . an absorbing community or voluntary work element (workfare components).

In order to properly understand this proposal, it is important to distinguish between a number of different threshold values - as shown in Table 1. 
Table 1: Threshold Values For the Four Component Model

\begin{tabular}{|c|c|c|}
\hline $\begin{array}{c}\text { Social/cultural } \\
\text { minimum income B }\end{array}$ & Single & $\begin{array}{c}\text { Family with 2 } \\
\text { children }\end{array}$ \\
\hline $\begin{array}{c}\text { Subsistence minimum } \\
\text { income (after halving } \\
\text { of ALG II) } \\
\text { B' }^{\prime}\end{array}$ & $€ 402.50$ & $€ 1,160$ \\
\hline $\begin{array}{c}\text { Break-even income Y* } \\
\text { Relative poverty line } \\
\text { (60\% of median } \\
\text { income based on OECD } \\
\text { formula) }\end{array}$ & $€ 840$ & $€ 1,781$ \\
\hline
\end{tabular}

(1) Social/cultural minimum income B

The social/cultural minimum income referred to above corresponds with the requirements of the household type in the status quo and is composed of the basic allowance (ALG II), social allowances for children, and the combined cost of housing and heating.

(2) Subsistence minimum income B' '

The subsistence minimum is not currently defined in the constitution. According to rulings on the Federal Social Assistance Act (BSHG) made in the social courts it would, however, be fair to assume that a $50 \%$ reduction in standard benefits in the case of a persistent refusal to accept work would not be overturned by the courts. A standard benefit for a single person of $€ 345$ (ALG II) could potentially be cut by $€ 172.50$, for example. In the case of standard benefits of $€ 622$ for both adults in a 
four-person family, it would be possible to cut benefits by $€ 311$. The children's social allowance and the reimbursement of housing and heating costs would remain in place. In some cases benefits in kind would be granted instead of monetary benefits in order to ensure that the needs of children are met.

(3) Break-even income $Y^{*}$

This income is the amount at which no further transfers are paid. To the right of $Y^{*}$ only taxes and fiscal charges are paid, while to the left of $Y^{*}$ transfer payments are made (although taxes and fiscal charges may, in certain circumstances, also be paid); $Y^{*}$ only lies on the $45^{\circ}$ line if no taxes and fiscal charges need to be paid.

(4) Relative poverty line

The relative poverty line is identical with the OECD definition found in the German government's report on the rich-poor divide (cf. Bundesregierung $2005)$. The OECD poverty line for singles is $60 \%$ of median income or $€ 938$ in 2004 . For a family this value is equivalent to a value of 1 for the first adult, 0.5 for the second adult and the figure 0.3 for each child in the household, adding up to €1970 (2.1 x €938) for two-child families.

Component 1: Degressive Unemployment Benefit Reduced Stepwise Over 12 Months

The first component is aimed at bringing about a change in the benefits side of the unemployment insurance equation. Instead of the current practice of limiting payment of unemployment benefits to 12 months and paying the benefit as a constant proportion of the claimant's last earned net income, the benefit could be paid at progressively lower levels over time (cf. the German Council of Economic Experts 2003). This would mean that the loss in income in the first few months of unemployment would be significantly lower than is currently the case, enabling search activities to be maximized. Within a period of one year, unemployment benefit would sink substantially as the total value of payments is to remain unchanged. 
At the same time, additional earnings up to the relative poverty line would continue to disregarded - in contrast to the current situation in which only $€ 165$ is disregarded and amounts over and above this are deducted in full from the insurance benefit.

\section{Component 2: Degressive TNIT}

Empirical studies based on experiments with control groups demonstrate the positive employment effects of time-restricted income supplements paid to the long-term unemployed (cf. Spermann/Strotmann 2005). International experience with time-restricted supplements - in Canada for example - have proved to be successful, as evaluation studies with control groups have shown (cf. Michalopoulos et al. 2005).

In principle TNIT is already part of the current basic jobseeker's allowance system and in fact 17,600 relevant cases were registered in 2005 (cf. Federal Labor Institute 2006b). Internal Federal Labor Institute guidelines also envisage the use of these back-to-work bonuses for self-employed people in particular (the "me incorporated [Ich-AG]" instrument and transitional benefits under the Social Code (SGB III) are not available to ALG II claimants). As a result $86 \%$ of financial support was dedicated to self-employed recipients and only $14 \%$ to the acceptance of employment subject to compulsory social insurance contributions. Practice differs markedly from region to region, however.

The state government of Saxony-Anhalt, for example - a region with a very high level of unemployment - has made massive use of these instruments with the outcome that around $60 \%$ of unemployed claimants receiving this form of support switched, with the aid of TNIT, into employment subject to compulsory social insurance (cf. Federal Labor Institute 2006b).

Whether or not supplementary financial support is granted continues to be at the discretion of case managers and the strategies adopted by individual job centers. Experiences with TNIT from pilot studies run in Baden-Württemberg and Hesse demonstrate, however, that case 
managers in the agencies often regard incentive instruments with considerable skepticism. They tend to adopt the argument that claimants are subject to a duty to seek and accept work and that there is therefore no need for any additional incentives. Differentiated analyses of administrative data at the national level are not yet available (studies in this direction will be launched by the IAB in the future).

The basic idea underlying TNIT is discussed in detail in Spermann (2001). In the current institutional framework, ALG II claimants are the target group for this supplementary payment. The continued development of TNIT links current time-restricted disregards of claimants' earned income with the relative poverty line for each type of household and a gradual and automatic reduction in ALG II (not of the social allowance) to a subsistence minimum income which conforms with constitutional requirements. The social/cultural minimum income for a single person is the current ALG II level of $€ 575$ (basic rate plus housing costs). The subsistence minimum income is $€ 402$ ( $50 \%$ of the basic rate plus housing costs). The relative poverty line as defined by the OECD and as used in the German government's report on the rich-poor divide is €938 for a single person or $60 \%$ of median income.

The following figures ( $3 a-c)$ illustrate the two components of this proposal drawing on the example of a single person:

After one year of unemployment, unemployed claimants receive basic jobseeker's allowance under SGB II if they successfully pass a tough means test. During the first month in which they are in receipt of benefits they are entitled to claim TNIT. Figure 3a demonstrates that in this way the income derived from a mini job is disregarded so that the poverty line of $€ 938$ can be reached. In other words, a mini job becomes just as attractive as moonlighting - if only for a limited period of time. In contrast to the situation today, a mini job is financially less attractive to claimants - with the outcome that only around $8 \%$ of those with mini jobs were 
previously unemployed (cf. Fertig et al. 2004). We may therefore anticipate that a combination of more stringently applied work requirements (the stick) and financial incentives (the carrot) will induce the long-term unemployed to step up their efforts to acquire mini jobs.

However, unless it is accompanied by other measures this incentive may well lead to new "stealth" employment - i.e. ALG II plus a mini job. It is for this reason that the TNIT must be degressive over time. This can be achieved by making automatic and gradual reductions in ALG II down to a constitutionally permissible subsistence minimum income. Figures $3 \mathrm{~b}$ and $3 c$ illustrate this additional incentive mechanism which pushes the longterm unemployed into earning more than they would in a mini job. The message is clear: unless they are more active in their job searching, they will have less disposable income. If, after the time-restricted TNIT income supplement has expired, the claimant's earnings are still only just sufficient to cover basic needs, the third component of the model comes into play.

The period for which TNIT is granted may vary according to the type of household concerned. The larger the household is, the longer the period during which TNIT is granted given that a higher net income is required in order to permanently escape the unemployment trap. 
Fig. 3(a): 2. Component - Month 1, Single Claimant, Western Germany

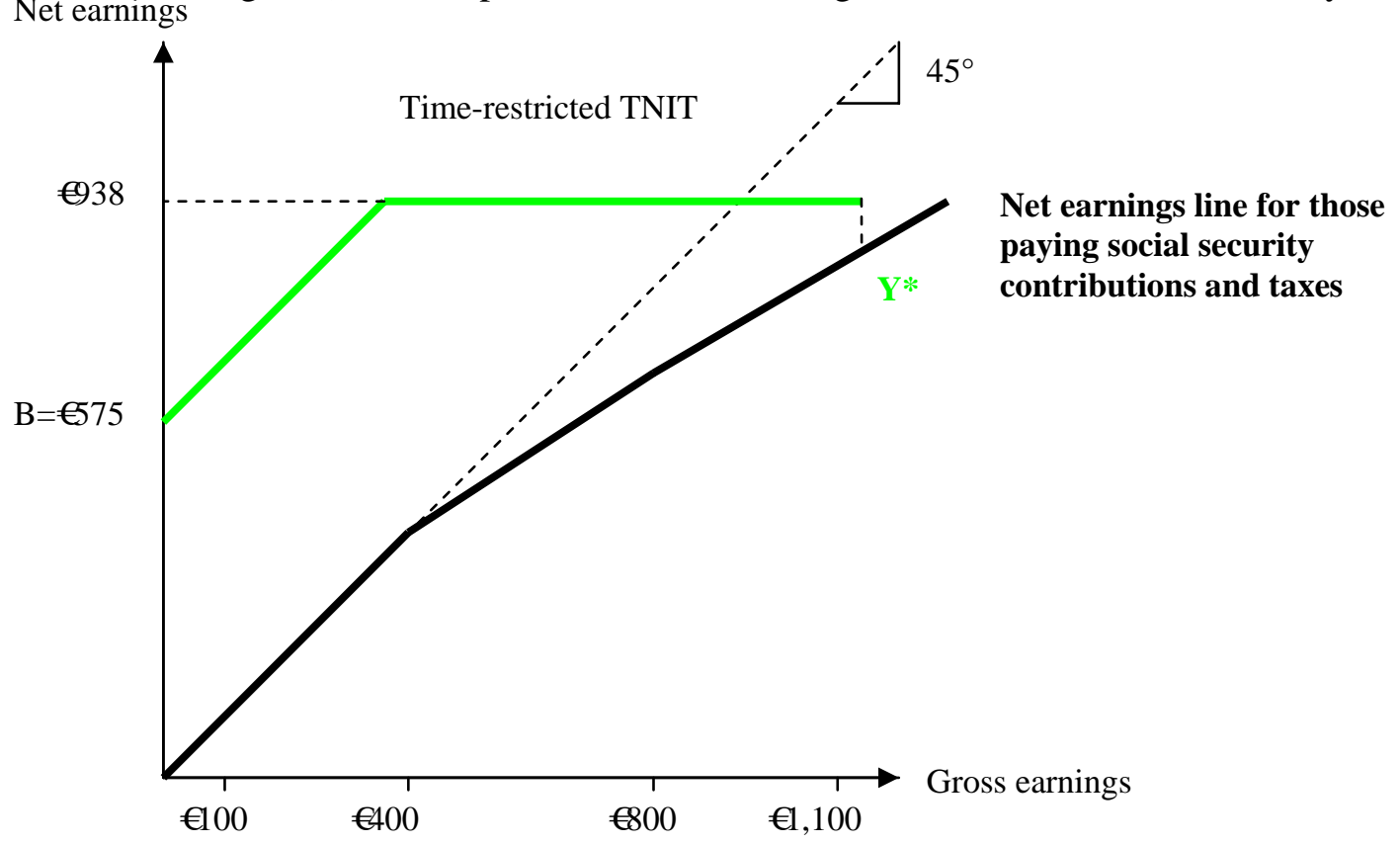

Fig. 3(b): 2. Component - Month 6, Single Claimant, Western Germany Net earnings

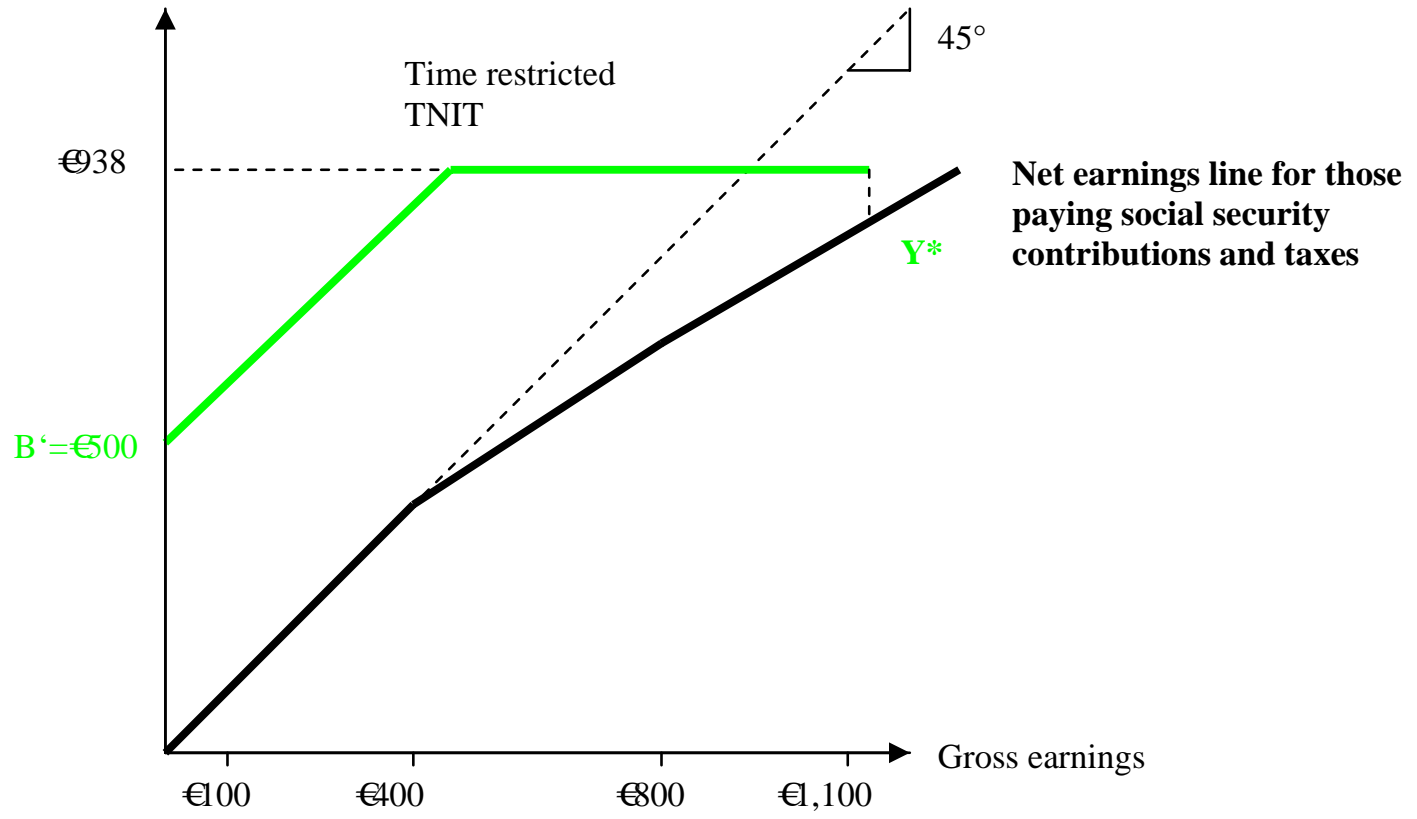


Component 3: Indefinite Basic Income Support Based on the Poverty Gap Concept

The third component provides for indefinitely payable basic income support at a subsistence minimum level - for future long-term unemployed claimants. This component is based on Milton Friedman's poverty gap concept $(1962 / 68)$. In the long run this component also does away with the unemployment trap. In contrast to the present system, there is an ongoing financial incentive to work more even after TNIT has expired. It is true that, at a benefit reduction rate of around $66 \%$, the marginal burden for claimants is relatively high - however, this could only be reduced further by either cutting ALG II levels even further ( $B$ " drops further) and/or lifting the transfer limit $Y^{*}$ so that it applies to higher gross earnings. Neither of these options would be advisable. A reduction beneath the subsistence minimum would conflict with constitutional requirements, and an increase in the transfer limit would entail an enormous additional fiscal burden.

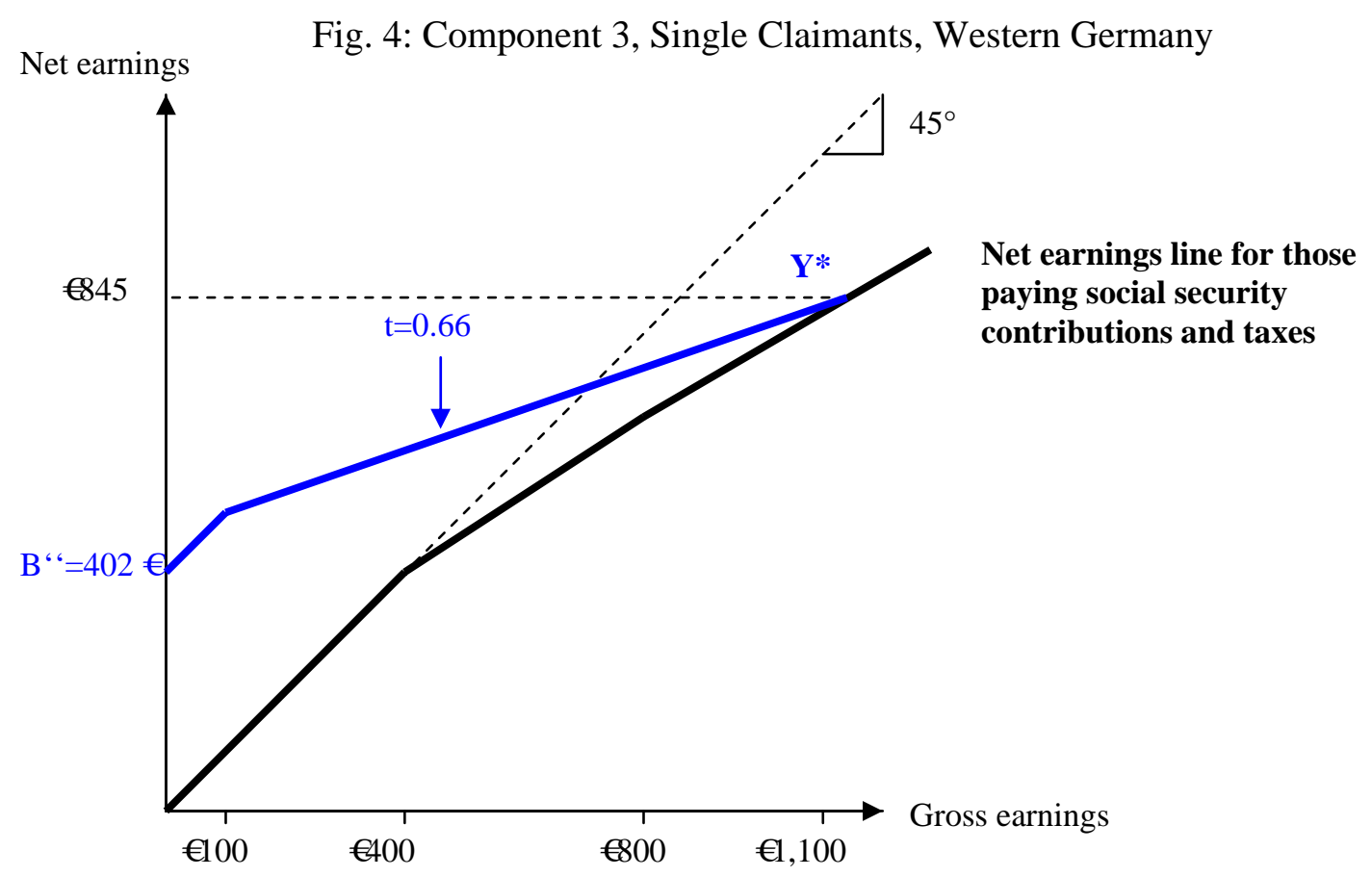


Similar scenarios can be mapped for larger households - although for space reasons these cannot be dealt with in this paper. Three points must, however, be underlined. First: The reduction to a subsistence minimum income level only relates to standard benefits, not however to the social allowance (cf. Table 1). Second: The TNIT for this type of household would push people towards accepting midi jobs (up to €800) or part-time employment - they would then be able to work their way out poverty under their own steam and, with the help of additional earnings, reach the relative poverty line of $€ 1,970$. Rising hourly wage rates (productivity effect) and more working hours (working hours effect) would, in certain circumstances, allow both partners to earn a gross income which would enable them to live permanently outside the transfer system. They would in any case remain in the working process so that their human capital would not be eroded by long-term unemployment and their social networks would be maintained.

Third: Even after TNIT expires - three years after a person becomes unemployed - there would still be a financial incentive to earn more even if the benefit reduction rate is relatively high at $71 \%$. This again underlines the crucial need to enforce the duty to seek and accept work. In a basic income support system which provides relatively generous income support, it will not be possible to offer permanent financial incentives (carrots) which will be able to compete at all with moonlighting, and it is therefore essential that the model is backed up by the duty to seek and accept work (sticks). 
Component 4: Community Work in Exceptional Cases (Workfare Component)

Any reform of basic income support aimed at improving financial incentives and tightening up the legal requirement to seek and accept work must offer a solution to the dilemma of how people who cannot find work on the labor market, despite their ability to demonstrate that they have made strenuous efforts, should be treated. This is where community work can play an important role - although as the exception rather than the rule.

Community work becomes relevant as soon as ALG II begins to fall. A social/cultural minimum income is intended to be secured with the help of community work - with working hours varying according to type of household - not, however, an income at the poverty line level. This ensures that it is always more worthwhile to accept private jobs than to undertake community work - in contrast to the current system in which one-euro jobs can prove to be financially more attractive than mini jobs, for example.

Community work would continue to be used to assess claimant's willingness to accept work. This instrument has proved effective in a) deterring people from making claims who are not in fact willing to accept work and $b$ ) ensuring that cuts in the benefits received by claimants who refuse work are legally watertight. On the other hand, it became apparent in 2005 that some ALG II claimants do not regard one-euro jobs as a sanction, but that these jobs are regarded as a welcome employment opportunity (cf. Koch et al. 2005). Community work thus fulfils a dual role as an instrument to check up on a claimant's willingness to accept work and to provide desirable occupations for the long-term unemployed who are unable to find employment on the open labor market. 


\section{Employment Effects and Fiscal I mpact}

Field studies with control groups in Germany have demonstrated that time-restricted income supplements - such as TNIT - increase the probability of employment (cf. Spermann/Strotmann 2005). Indefinitely payable income supplements based on the poverty gap concept - in other words a reduction in benefit levels and lower benefit reduction rates have positive employment effects, as simulation studies performed by the ZEW with the general equilibrium model show (Boeters et al. 2003). Positive employment effects are even more probable if a reform of basic income support is backed up by labor law reforms (shorter dismissal protection periods and lower back-to-work wages for the long-term unemployed) and collective bargaining measures (larger wage spread). Positive employment effects would bring fiscal savings with them.

The author of this paper can only speculate however on the extent and sustainability of these employment effects and the resulting fiscal impact. Neither microsimulation studies nor general equilibrium models are capable of producing reliable results because ultimately both are based on the behavioral responses of people in a world in which a legal low-wage sector is, to all intents and purposes, very small or even non-existent. Empirical elasticities on which such models draw, are based on observations in wage segments which exist today - it goes without saying that they cannot be based on the responses of people in an, as yet, nonexistent low-wage sector. The significance of non-cognitive abilities in filling jobs in a low-wage service sector continues to be underestimated (cf. Hieming et al. 2005). For this reason well-founded skepticism is warranted as far as model calculations are concerned which promise major employment gains and high levels of fiscal savings. 
What is more, the available empirical ex ante microsimulations for the low-wage sector are only able to capture partial effects and to provide educated guesses about where the impact will be felt. Microsimulations of mini jobs are not, for example, able to capture the basic impact of sideline employment, as this type of model only allows for the simulation of changes in main occupations (cf. Arntz/Feil/Spermann 2003 and Steiner/Wrohlich 2004). Impressive though this is, it nonetheless only covers part of the overall picture.

Empirical studies with existing simulation models are, however, able to demonstrate under what circumstances neutral or negative employment effects and additional fiscal burdens may arise. The introduction of a minimum wage would be counterproductive - existing jobs below the agreed minimum wage would be destroyed, new jobs in the low-wage sector would not be created at all. A combi-wage reform which expanded the population of entitled claimants would be fiscally extremely risky: additional fiscal burdens would be guaranteed, but the additional employment effects in an inflexible labor market would be highly uncertain. High minimum wages and an across-the-board combi-wage for the low-skilled under existing legal and collective bargaining restraints would prove a fiasco.

\section{The Advantages of the Gradualism Strategy Compared with the Cold Turkey Strategy}

Bearing in mind the many imponderables and the lack of empirical clarity regarding the level of employment effects, as well as the resulting fiscal impact, this paper argues in favor of a gradual strategy - in contrast to a cold turkey strategy which promises an immediate reduction in benefit levels and substantially higher employment of up to 3.2 million people in work, plus fiscal savings of up to 21 billion euros (cf. Sinn et al. 2006). 


\section{Fairness Considerations}

For reasons of fairness, the combi-wage reform coupled with an automatic trimming down of basic income support to a subsistence minimum should only be focused on future ALG II claimants who would be able to adjust their behavior accordingly in good time.

As far as existing ALG II claimants are concerned - those who have previously been in employment for many years and who have slipped into long-term unemployment as a result of structural changes - fairness would dictate a different approach. Current ALG II claimants have received the message over decades of their working lives that, should they become unemployed, they would be able to rely on a system of unemployment insurance which would provide them with a transfer income coupled to their previous take-home pay. All the economic decisions taken by this group have also been taken in this framework. The merging of unemployment assistance and social assistance at social assistance levels has already produced several hundred thousand reform losers (cf. Rudolph/Blos 2005). It would be inappropriate to further reduce the benefits payable to this group of people, who would then be forced to engage in community work in order to maintain the level of their benefit entitlements.

Existing ALG II claimants could, however, be at least motivated to take up mini, midi and part-time jobs if adjustments were made to the additional earnings regulations. Where these mini jobs entail more than 15 -hours of work a week, these ALG II claimants would no longer be counted as unemployed, even if they continued to receive supplementary ALG II. A realistic intermediary target for a combi-wage reform for existing ALG II might be the loss of "unemployed" status. As approximately 2.8 million ALG II claimants are registered unemployed, this would represent a major 
step in the right direction, and one that would substantially reduce the fiscal burden. It should prove easier for people to find fulltime employment if they already have a job than would be the case if they were to seek work as an unemployed applicant.

Reduced Scope of Community Work

A combination of time-restricted and permanent income supplements would almost certainly reduce the scale of community work undertaken in comparison with a cold turkey strategy. On the one hand, the long-term unemployed may move out the basic income support system within the time limits as a result of rising wages and higher hourly wage rates - they are able to find their way into the labor market and, in certain circumstances, break out of the basic income system without being dependent on community work. On the other hand, benefits received by future ALG II claimants would only gradually be reduced to a subsistence minimum so that more time would be available to seek a job in the private labor market.

Avoiding the Production of Working Poor

A further element of the four component model is the link between time restricted income supplements and the poverty line. This can enable the long-term unemployed to work their own way out of poverty - and out of the category of the working poor - within a specified timeframe. A substantial number of long-term unemployed people may be expected to remain in employment once they have managed the leap into the private labor market. The lessons learned from field experiments with TNIT in Germany suggest that people tend to get used to higher incomes - around $60 \%$ of those receiving TNIT support remained in employment even after the scheme had expired (cf. Dann et al. 2002). 


\section{Conclusion}

A cautious change of system to a combi-wage system would appear to be an appropriate way of enabling people and institutions to adapt - in particular with regard to labor law and collectively agreed structures (gradualism strategy). A distinction must, however, be made between future long-term unemployed people and existing long-term unemployed claimants. Those who become unemployed in the future should receive a clear message from the state that their state income supplement will drop to a subsistence minimum wage level and that individual effort combined with generous disregard rules make a life above the poverty line possible. The status of a member of the working poor can be avoided by individual effort. The four component model describes such a system consisting of time-restricted and indefinitely payable income supplements with an automatic reduction in basic income support to the level of a subsistence minimum income. At the same time, current unemployed ALG II claimants should - out of fairness considerations - only be offered generous timerestricted income supplements (TNIT) to motivate them to work at least 15 hours a week and thus to lose their status as unemployed.

The danger inherent in a fast change of system (cold turkey strategy) in which benefits for all ALG II claimants are immediately and substantially reduced is that the employment effects promised by its protagonists will not materialize in anything like the near future because the behavioral responses in the low-wage sector have been incorrectly understood and non-cognitive abilities crucial for successful job matches are ignored. If employment effects fail to materialize, fiscal savings above and beyond those arising from cuts in ALG II alone would not be realized. This would entail the establishment of community work opportunities on a major scale which would again generate very high fiscal costs. The net fiscal effect is uncertain. The logical conclusion is: Better gradualism than cold turkey. 


\section{References}

Arntz, M. / Feil, M. / Spermann, A. (2003): Die Arbeitsangebotseffekte der neuen Mini- und Midi jobs - eine ex-ante Evaluation, Mitteilungen aus der Arbeitsmarkt- und Berufsforschung 36, 271-290.

Boeters, S. / Schnabel, R. / Gürtzgen, N. (2003): Reforming Social Security in Germany - An Applied General Equilibrium Analysis, ZEW Discussion Paper 03-70, ZEW, Mannheim.

Dann, S. / Kirchmann, A. / Spermann, A. / Volkert, J. (2002): Einstiegsgeld in Baden-Württemberg, Schlussbericht, in: BadenWürttemberg Ministry of Socia Affairs (publisher), Stuttgart.

Dietz, M. / Koch, S. / Walwei, U. (2006): Kombilohn, Ein Ansatz mit Haken und Ösen, IAB-Kurzbericht Nr. 3 v. 1.3.2006, Nuremberg.

Federal Labor Institute (2005): Der Arbeits- und Ausbildungsmarkt in Deutschland, Monthly Reports for December and the year 2005, Nuremberg.

Federal Labor Institute (2006a): Der Arbeits- und Ausbildungsmarkt in Deutschland, Monthly Report March, Nuremberg.

Federal Labor Institute (2006b): Grundsicherung für Arbeitsuchende, Annual Report 2005, Nuremberg.

Federal Labor Institute (2006c): Grundsicherung für Arbeitsuchende, Anrechenbare Einkommen und Erwerbstätigkeit, March, Nuremberg. 
Federal Government of the Federal Republic of Germany (2005): Lebenslagen in Deutschland, Der 2. Armuts- und Reichtumsbericht der Bundesregierung, Berlin.

Fertig, M. / Kluve, J. / Scheuer, M. (2004): Aspekte der Entwicklung der Mini jobs, Essen.

Friedman, M. (1962): Capitalism and Freedom, Chicago.

Friedman, M. (1968): The Case for the Negative Income Tax, in: Melvin, L. (publisher): Republican Papers, 202-220.

Hieming, B. / Jaehrling, K. / Kalina, T. / Vanselow, A. / Weinkopf, C. (2005): Stellenbesetzungsprozesse im Bereich „einfacher“ Dienstleistungen, Dokumentation Nr. 550, published by Federal Ministry of Economics and Labor, Berlin.

Kaltenborn, B. (2001): Kombilöhne in Deutschland, Eine systematische Übersicht, IAB-Werkstattbericht Nr. 14, Nuremberg

Kaltenborn, B. et al. (2005): Evaluierung der arbeitsmarktpolitischen Sonderprogramme CAST und Mainzer Modell, Forschungsbericht $\mathrm{Nr}$. 552, published by Federal Ministry of Economics and Labor, Berlin.

Koch, S. / Stephan, G. / Walwei, U. (2005): Workfare: Möglichkeiten und Grenzen, IAB Discussion Paper No. 17/2005, Nuremberg.

Michalopoulos, C. / Robins, P.K. / Card, D. (2005): When financial work incentives pay for themselves: evidence from a randomized social experiment for security claimants, Journal of Public Economics 89, 529. 
OECD (2005): Employment Outlook, Paris.

Reinberg, A. / Hummel, M. (2005): Höhere Bildung schützt auch in der Krise vor Arbeitslosigkeit, IAB-Kurzbericht Nr.9/2005, Nuremberg, 2005.

Rudolph, H. / Blos, K. (2005): Schätzung der Auswirkungen des Hartz-IVGesetzes auf Arbeitslosenhilfe-Bezieher, IAB-Forschungsbericht Nr. 14/2005, Nuremberg.

Sachverständigenrat zur Begutachtung der gesamtwirtschaftlichen Entwicklung (2003): Jahresgutachten 2003/04: Staatsfinanzen konsolidieren - Steuersystem reformieren, Wiesbaden.

Sachverständigenrat für die gesamtwirtschaftliche Entwicklung (2005): Die Chance nutzen - Reformen mutig vorantreiben, Jahresgutachten 2005/06, Wiesbaden.

Schöb, R. / Weimann, J. (2005): Arbeit ist machbar. Die Magdeburger Alternative: Eine sanfte Therapie für Deutschland, 4. Aufl., Dößel.

Sinn, H.-W. et al. (2002): Aktivierende Sozialhilfe, Ein Weg zu mehr Beschäftigung und Wachstum, ifo-Schnelldienst Nr. 9, Munich.

Sinn, H.-W. et al. (2006): Aktivierende Sozialhilfe 2006: Das KombilohnModell des ifo Instituts, ifo schnelldienst Nr. 2, Munich.

Spermann, A. (2001): Negative Einkommensteuer, Lohnsubventionen und Langzeitarbeitslosigkeit, Finanzwissenschaftliche Schriften Bd. 104, Frankfurt am Main. 
Spermann, A. (2006): Der Kombilohn: Chancen, Gefahren und Erfahrungen aus Modellversuchen, erscheint in: Wirtschaftspolitische Blätter.

Spermann, A. / Strotmann, H. (2005): The Targeted Negative Income Tax (TNIT) in Germany: Evidence from a Quasi Experiment, ZEW Discussion Paper 05-68, ZEW, Mannheim.

Steiner, V. / Wrohlich, K. (2004): Work Incentives and Labor Supply Effects of the 'Mini jobs Reform' in Germany, DIW Discussion Papers 438, Berlin. 